M.I. Baranov

\title{
AN ANTHOLOGY OF THE DISTINGUISHED ACHIEVEMENTS IN SCIENCE AND TECHNIQUE. PART 44: TRADITIONAL POWER ENGINEERING. NUCLEAR POWER STATIONS: RETROSPECTIVE VIEW, STATE AND PROSPECTS OF THEIR DEVELOPMENT
}

Purpose. Preparation of brief scientific and technical review about a retrospective view, modern state, achievements, problems, tendencies and prospects of development of world nuclear energy. Methodology. Known scientific methods of collection, analysis and analytical treatment of the opened scientific and technical information, present in scientific monographs, journals and internet-reports, world level in area of nuclear energy. Results. A brief analytical scientific and technical review is resulted about a retrospective view, modern state, basic achievements, existent problems, tendencies and prospects of development of nuclear energy in the industrially developed countries of the world. Considerable progress is marked in development and creation of technical base of modern nuclear energy, including the nuclear power stations (NPP) such their basic devices as nuclear reactors, steam generators, steam turbines and turbogenerators. The basic charts of construction of NPP producing in the world now about $11 \%$ are described annual production electric power. It is indicated that in Ukraine a production of electricity volume at NPP makes more than $50 \%$, and in France - more than $70 \%$ in annual power balance of country. Nuclear-physical bases of work of nuclear reactor are resulted on thermal-neutron, widely in-use at NPP. The design of most safe water-waters of nuclear power-reactor of type of WWER-1000 is described by thermal power $1000 \mathrm{MW}$, applied presently at NPP of Ukraine. Basic classification of nuclear reactors is presented. Technical information is resulted about largest NPP of the world. Master data are indicated about a nuclear fuel and radio-active offcuts of nuclear reactors of NPP. Basic measures and facilities are described for the increase of safety of nuclear reactors and NPP. Advantages and lacks of NPP are marked by comparison to the thermal power plants. Nuclear energy of Ukraine is considered and basic technical descriptions of operating domestic NPP are indicated. Basic problems, tendencies and possible prospects of development, are marked in the world and to Ukraine of nuclear energy. Originality. Systematization of the scientific and technical materials touching functioning of such important sector of world economy as nuclear energy known from the sources opened in outer informative space is executed. It is shown on the basis of approach of the systems that in spite of row of existent problems in area of world nuclear energy has the real prospects in the further development and to service society at satisfaction of his increasing requirements in electric and thermal energies. Practical value. Popularization and deepening for students, engineer-technical and scientific workers of scientific and technical knowledge in area of modern nuclear physics and energy, extending their scientific range of interests and further development of scientific and technical progress in society. References 20, figures 13, tables 1.

Key words: nuclear physics and energy, nuclear reactor, nuclear power station, safety of nuclear reactor and nuclear power station, problems and prospects of development of nuclear energy.

Приведен краткий научно-технический обзор о ретроспективе, современном состоянии и тенденциях в развитии мировой ядерной энергетики. Приведены ядерно-физические основы функционирования и описаны основные устройства ядерного реактора на уране и тепловых нейтронах, широко используемого на атомных электрических станциях (АЭС). Представлена классификация ядерных реакторов. Приведены данные о применяемом на АЭС ядерном топливе и радиоактивных отходах ядерных реакторов АЭС. Указаны меры для повышения безопасности ядерных реакторов и АЭС. Отмечена важная роль АЭС в годовом объеме выработки электроэнергии в мире и ряде стран. Указаны преимущества и недостатки АЭС. Рассмотрена ядерная энергетика Украины. Обозначены основные проблемы и перспективы развития в мире и Украине ядерной энергетики. Библ. 20, рис. 13. табл. 1.

Ключевые слова: ядерная физика и энергетика, ядерный реактор, атомная электрическая станция, безопасность ядерного реактора и атомной электрической станции, проблемы и перспективы развития ядерной энергетики.

Introduction. As is known, for the first time in the world, a controlled chain nuclear reaction in natural uranium ${ }_{92}^{238} \mathrm{U}$ containing not more than $0.71 \%$ per unit weight a rare isotope of uranium ${ }_{92}^{235} \mathrm{U}$ fissioning by slow (thermal) neutrons [1], was carried out on December 2, 1942 by a group of physicists and engineers of the University of Chicago (USA) headed by the Nobel Prize winner in physics for 1938, Professor Enrico Fermi [2, 3]. The world's first uranium-graphite nuclear reactor in the form of an ellipsoid of rotation (with polar by vertical radius of about $3.09 \mathrm{~m}$ and equatorial by horizontal radius of about $3.88 \mathrm{~m}$ ) known as «Chicago Pile-1» or CP-1 and containing 57 layers of uranium-graphite blocks (with 46 tons of natural uranium, of which 6 tons was metal uranium and 40 tons uranium dioxide and 385 tons of block uranium graphite of extraordinarily high purity [3]), ensured the receipt of a self-sustaining controlled (due to the radial neutrons of the cadmium rods, radiated through five three-level horizontal channels into the active zone of the reactor), the chain nuclear reaction [2]. With a minimum energy release power level (about $0.5 \mathrm{~W}$ ) and radioactivity for personnel in this uncooled nuclear reactor, the multiplication factor $k_{p}$ of neutrons was almost equal to unity [3]. By $k_{p}$ which determines the reactivity $\rho_{p}=\left(k_{p}-1\right)$ of the nuclear reactor we mean the ratio of the number of neutrons in one of the succeeding generations from the fission of the nuclei of the uranium isotope ${ }_{92}^{235} \mathrm{U}$ to their number in the previous generation from the fission of these nuclei [1]. It was the creation of a uranium-graphite nuclear reactor that opened the main path to the military and peaceful use of the nuclear energy of a number of radioactive chemical elements (for example, the uranium isotope ${ }_{92}^{235} \mathrm{U}$ and the isotope of plutonium $\left.{ }_{94}^{239} \mathrm{Pu}[1,3]\right)$. It should be noted that in the framework of the Uranium project of Nazi Germany (the scientific advisor of the project was Nobel Prize winner in physics for 1932, Professor Werner Heisenberg), a fully- 
fledged controlled nuclear chain reaction in uranium ${ }_{92}^{235} \mathrm{U}$ was obtained only in February 1945 in an experiment conducted in the mining near Haigerloch [2]. After almost two months, Germany's nuclear program, due to the defeat of the latter in the Second World War, ceased to exist. Let us also point out that in the former USSR the first Soviet experimental uranium-graphite nuclear reactor created under the scientific supervision of Academician of the Academy of Sciences of the USSR Igor Vasilievich Kurchatov at Laboratory No. 2 (now Russian Research Center «Kurchatov Institute», Russian Federation (RF), Moscow) and called F-1 (in my opinion, the letter $\langle\mathrm{F}\rangle$ in the name of the reactor comes from the name of the outstanding Italian-American nuclear physicist Fermi, the first to invent this type of heterogeneous nuclear reactor; this is a kind of homage of Soviet nuclear physicists to this all worldwide known scientist), on December 25, 1946 was put into its critical state $\left(k_{p} \approx 1\right)$ [2]. Reactor F-1 was almost a ball with a diameter of up to $7.5 \mathrm{~m}$, in the central part of which a diameter of about $6 \mathrm{~m}$ along the holes in the graphite blocks were placed working uranium and controlled cadmium rods. It did not have a cooling system and therefore operated at minimum power levels. Based on the experimental data obtained at the F-1 reactor, in July 1948 in the Southern Urals (Ozersk city), the first Soviet industrial uranium-graphite reactor, called A-1, was designed to produce weapons grade plutonium ${ }_{94}^{239} \mathrm{Pu}$ for the first Soviet atomic bombs [2, 4]. It is important to emphasize that as early as 1948 (before the completion of the work on the creation of the first Soviet plutonium atomic bomb successfully blown up at the Southern Nuclear Test Site of the USSR on August 29, 1949 [4, 5]) Academician of the Academy of Sciences of the USSR I.V. Kurchatov achieved, by the appropriate decision of the Government of the USSR, the initiation of experimental and development work on the practical peaceful use of atomic energy to generate electricity. In May 1950, in Obninsk (Kaluga region, RF), where one of the Soviet leaders in the field of reactor building, the «Physico-Energy Institute» (now the world-famous State Research Centre of the RF «Physics and Power Institute named after A.I. Leypunsky» [6]) placed, construction of the Obninsk nuclear power plant (NPP) with installed capacity of 5 MW began [2]. June 27, 1954 Obninsk NPP (Fig. 1) was put into trial operation. It was the first in the world NPP connected to a common electrical network [2].

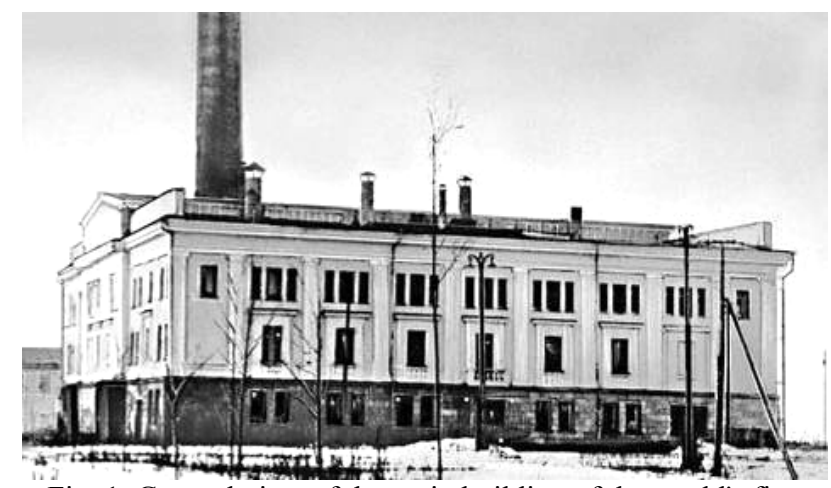

Fig. 1. General view of the main building of the world's first pilot industrial Obninsk NPP with installed power of $5 \mathrm{MW}$ (Obninsk, Kaluga region, RF, 1954) [7]
In 1958, the first stage of the Siberian NPP (Tomsk city) was commissioned in the former USSR with power of $100 \mathrm{MW}$ (soon this NPP was brought to design power of $600 \mathrm{MW}$ ) [2]. On April 26, 1964, the first stage of the Beloyarsk NPP (Middle Urals, RF) gave electric current to its consumers. In September 1964, the 1st power unit of the Novovoronezh NPP was commissioned with installed power of $210 \mathrm{MW}[2,7]$. The 2 nd power unit of this NPP with installed power of $365 \mathrm{MW}$ was launched in December 1969. In 1973, the first power unit of the Leningrad NPP with installed power of 1000 MW was commissioned. We point out that outside the former USSR the first industrial NPP with installed power of 46 MW was put into operation in 1956 in Calder Hall (Great Britain) [2]. In 1957, the US launched its first NPP in Shippingport with installed power of $60 \mathrm{MW}$. In 1959, France built its first NPP, Germany in 1961, Canada in 1962, Sweden in 1964 and Japan in 1966 [2, 7]. In 1976, around the world, work was begun on the construction of a record number of NPP in the history of world nuclear power, numbering 44 new nuclear power plants. In 1979, a serious accident occurred in the United States at the Three Mile Island nuclear power plant, which led to the long-term «freezing» of the US nuclear power program [2]. It should be noted that in the United States the idea of putting into operation new peaceful nuclear facilities was not returned until the beginning of the 21 st century. Only during 1984-1985, in the world 33 new nuclear power plants were built [2]. The massive catastrophe on April 26, 1986 at the Chernobyl nuclear power plant (the explosion of the nuclear reactor of the 4th power unit with power of $1000 \mathrm{MW}$ ) had a negative impact not only on the nuclear power of the former USSR and then on independent Ukraine, but on the entire nuclear power industry of the industrialized countries. Undoubtedly, the recent catastrophe at the Fukushima-1 nuclear power plant, which occurred in March 2011 in Japan due to a strong earthquake in the nearby fault zone of the Earth's crust and the huge ocean waves (tsunami) that followed it, had a negative impact on the world nuclear power industry [8]. Undoubted scientific, technical and educational interest is an overview of the current state and possible prospects for the development of world nuclear energy, which has great socio-economic significance for mankind.

The goal of the paper is compilation on the basis of published materials of a scientific and technical review on the retrospective, current state, main achievements, problems and prospects for the development of nuclear power in the world with its powerful nuclear power plants.

1. General characteristics of nuclear power plant, its main construction schemes and power units. As is known, NPP is an important strategic object of any country in the world, containing a nuclear installation with the necessary technical facilities and technological systems, intended for industrial production of electricity (heat) $[7,8]$. The cost of building a NPP according to modern expert estimates is about USD 2300 per $1 \mathrm{~kW}$ of electric power of this nuclear installation, commonly called a «nuclear reactor» [8]. Proceeding from this, the approximate cost of building at a NPP of its one 1000 
MW power unit will be at least USD 2.3 billion. As we can see, nuclear power is the branch of the country's economy that requires huge investments. In Fig. 2, 3 in enlarged form the schemes of construction of modern nuclear power plants with powerful nuclear reactors and power units of increased safety are given $[2,7,8]$.

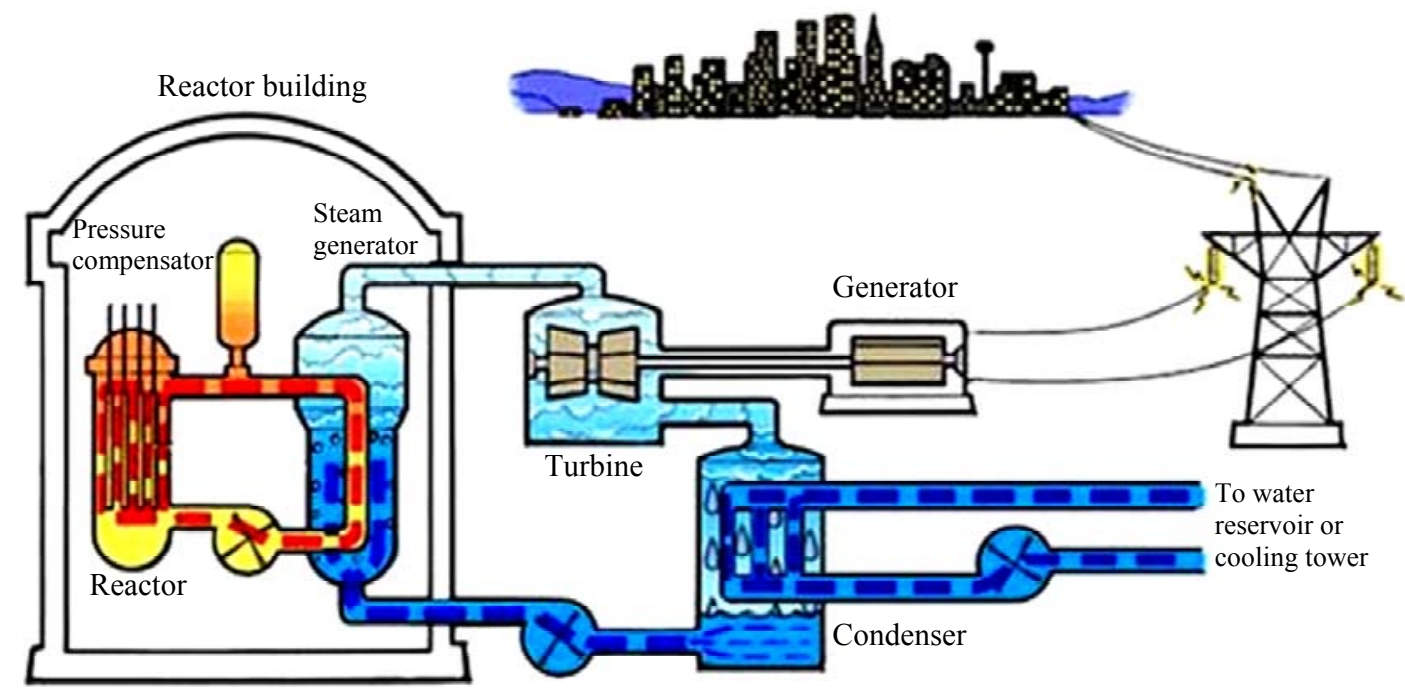

Fig. 2. Scheme of modern NPP on a two-circuit water-water power nuclear reactor of the WWER-1000 type [8]

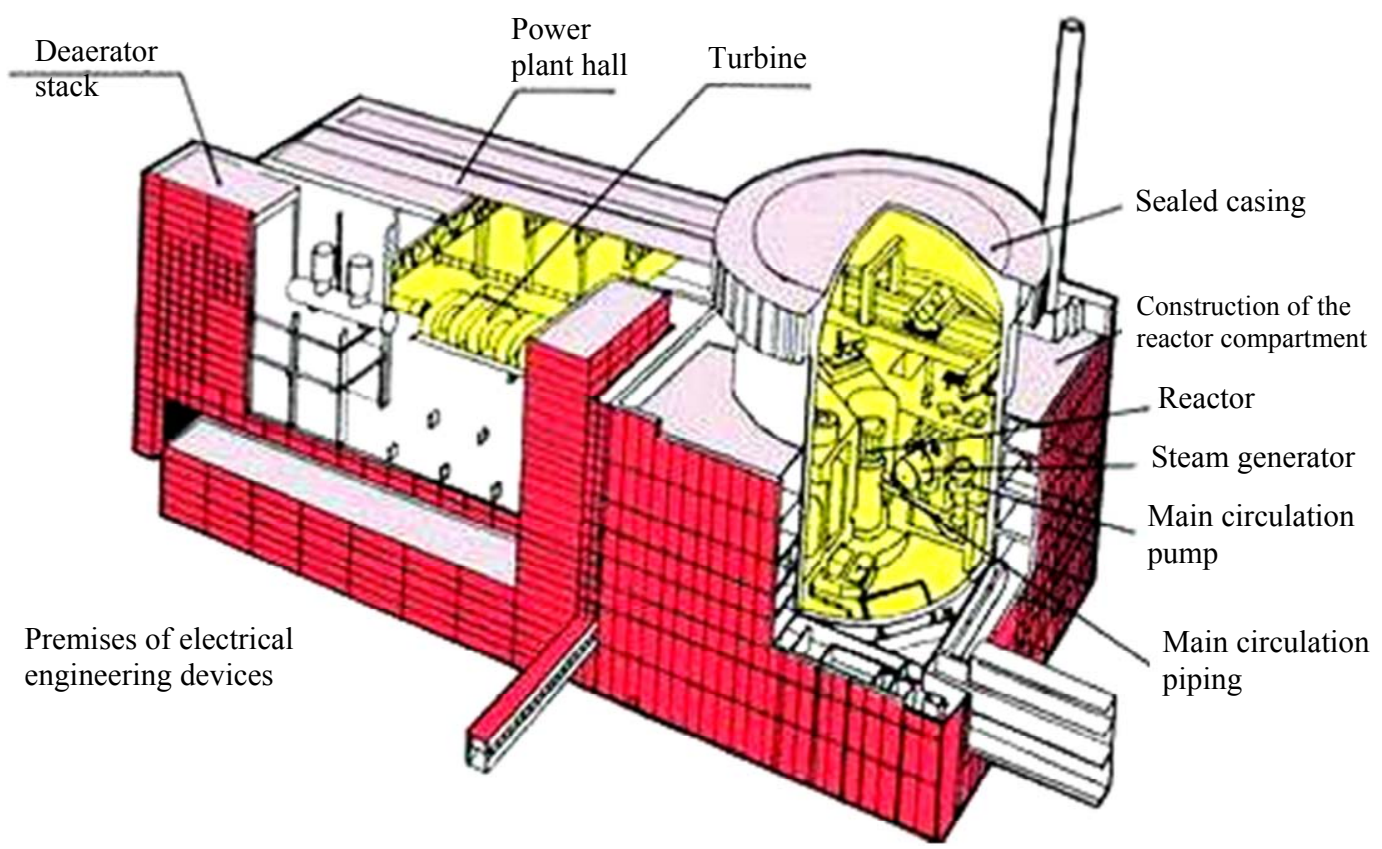

Fig. 3. Scheme of the structure of a powerful power unit of a modern NPP with a nuclear reactor of the WWER-1000 type [8]

According to Fig. 2, 3, the core of the NPP and its each power unit is a nuclear reactor (our accepted abbreviation WWER-1000 stands for «1000 MW waterwater power reactor») which converts purified water with the addition of a solution of boric acid to a non-boiling boron mixture with a temperature of up to $320^{\circ} \mathrm{C}$, directed by the main circulation pump along the first radioactive circuit to the steam generator.

The operating pressure of the boron-water mixture in the first circuit of a nuclear reactor of the WWER1000 type is up to $160 \mathrm{~atm}(16.2 \mathrm{MPa})$ [8]. The pressure compensator in this circuit serves to equalize the pressure fluctuations caused by the thermal expansion of its coolant. In the heat exchanger of the steam generator, this mixture heats the water of the second nonradioactive closed circuit to boiling, the superheated steam is directed to a steam turbine at pressure of about $63 \mathrm{~atm}$ (see Fig. 2, 4) rotating the rotor of a synchronous generator producing electricity. From the outlet pipe of the steam turbine, the spent steam is sent to a condenser, where it is cooled by water flows from the cooling pond (cooling tower) and by means of a circulating pump of this closed circuit is fed back to the heat exchanger of the steam generator. Note that the use of liquid metal coolant (for example, sodium) in the primary circuit instead of water makes it possible to simplify considerably the design of its metal casing in the core (the pressure of its liquid metal coolant does not exceed atmospheric pressure) and to get rid of it from the pressure compensator $[7,8]$. Let us dwell further on the nuclear-physical features of the operation of powerful nuclear reactors of nuclear power plants. 


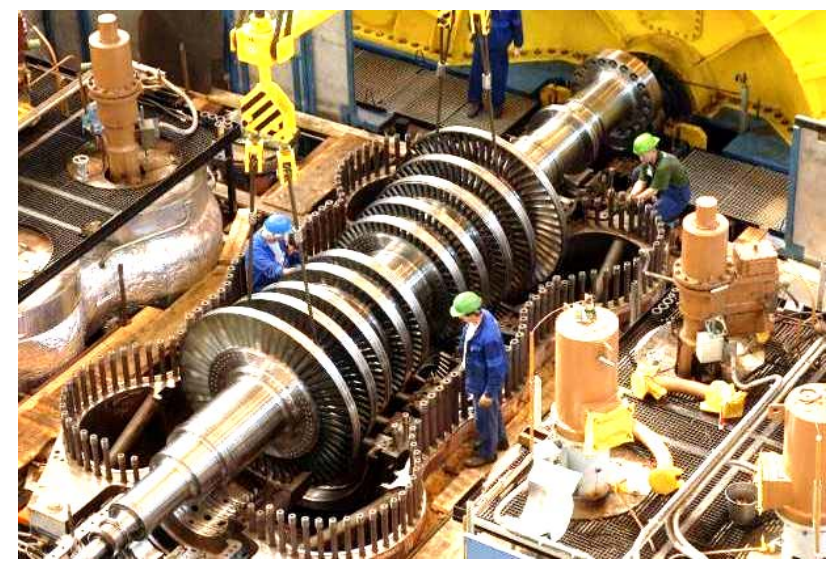

Fig. 4. Installation of a powerful domestic steam turbine ПT-1000 (in the right side of the turbine axis, the body of the corresponding turbogenerator is visible) in the power plant hall of the NPP [9]

1.1. Nuclear physics and nuclear reactor. From atomic physics it is known that the energy barrier hinders the spontaneous transition of a microparticle of matter to a different state. It can overcome this barrier only in two ways [1]: either due to the kinetic energy of the colliding particles, or due to the binding energy of the joining particle. The excitation of matter by the attached particles does not require large values of their kinetic energy. The main thing here is to have these particles, leading to «exoenergetic reactions» occurring in the excited substance, in which, in the subsequent transformation of the substance, energy is released more than required for its excitation itself. When energy is obtained in this way on a macroscopic scale, such reactions in matter must be chain-like, following one after another. Chain reactions in a substance can arise only when the particles that excite it in the exoenergetic reaction appear again as a product of the course of these exoenergetic reactions. Nuclear physicists have long been looking for a similar substance (chemical element) and similar microparticles, leading to the emergence of «chain nuclear reactions» in it and, accordingly, to the allocation of large values of intranuclear energy. In January 1939, the AustrianGerman «tandem» of physicists Otto Frisch and Lisa Meitner, interpreting the results of a nuclear experiment conducted in December 1938 by German scientists Otto Hahn and Fritz Strassmann, concluded that in the natural uranium ${ }_{92}^{238} \mathrm{U}$ the nuclear reaction of dividing the «mother» nuclei of its $_{92}{ }^{238} \mathrm{U}$ isotope into two fragments with their «daughter» nuclei and the emission of several fast neutrons $[3,10]$. The scientific discovery of the chain nuclear fission reaction in the uranium isotope ${ }_{92}^{238} \mathrm{U}$ pointed to the practical reality of mastering nuclear energy for both military and peaceful purposes. Now we know that for each act of fission of one nucleus of the uranium isotope ${ }_{92}^{238} \mathrm{U}$, energy of about $197 \mathrm{MeV}$ $\left(3.15 \cdot 10^{-11} \mathrm{~J}\right)$ is released and an average of 2.47 fast neutrons are «born» (produced) [1, 3]. Most of the fast neutrons (with energies up to $0.7 \mathrm{MeV}$ [1]) are emitted almost instantaneously (in a time on the order of the relaxation time of free electrons in a copper conductor $\left.10^{-14} \mathrm{~s}[1]\right)$, and about $0.75 \%$ of all secondary neutrons is emitted by nuclear fission fragments with delay in time equal to $(0.05-60) \mathrm{s}[1,3]$. Such neutrons in nuclear physics are called «delayed», which play an important role in the management of nuclear chain reactions in nuclear power plant reactors operating on thermal neutrons. For a stable course of the nuclear chain reaction in the uranium isotope ${ }_{92}^{235} \mathrm{U}$, impurities that absorb neutrons should be absent in it, and a minimum amount of a nuclear substance called the critical mass should be present $[1,3]$. In addition, the neutron energy in the core with nuclear fuel should be sufficient to cause fission of the nuclei of the uranium isotope ${ }_{92}^{235} \mathrm{U}$. When using slow neutrons in the reactor for these purposes, their energy is $\sim 0.025 \mathrm{eV}[1,3]$. A controlled chain nuclear reaction in the uranium isotope ${ }_{92}^{235} \mathrm{U}$ underlies the construction of nuclear reactors operating on slow neutrons and used at nuclear power plants. Fig. 5 shows a unique photo image of the core of a working water-cooled nuclear reactor [2].

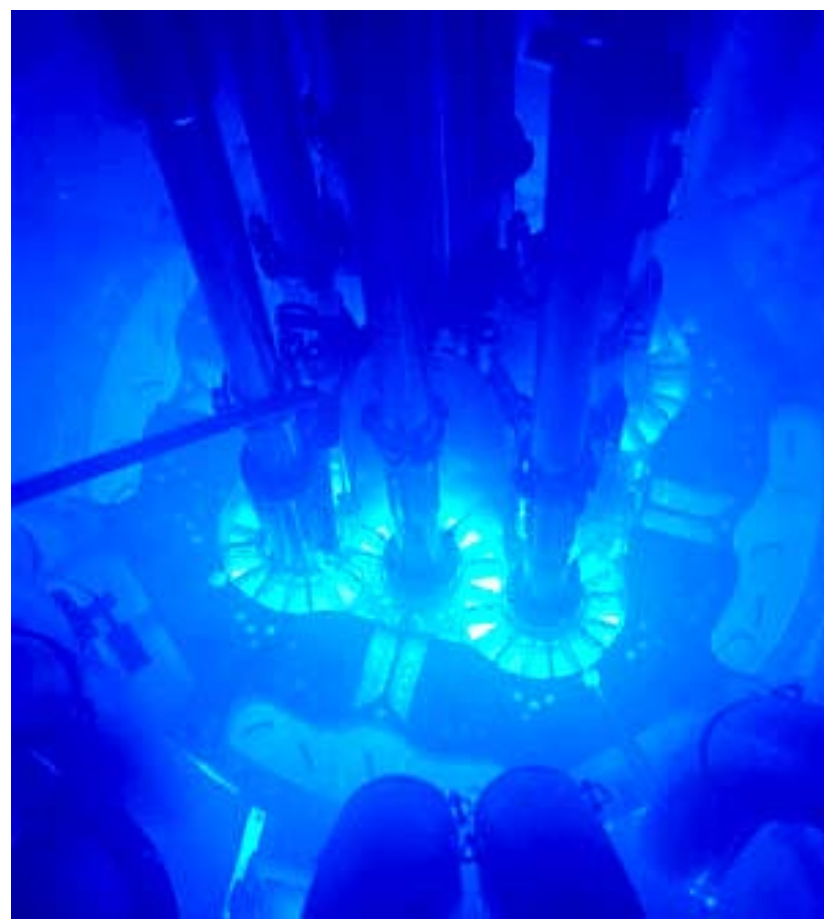

Fig. 5. The rarest view of active zone of the active research water-water nuclear reactor (in the active zone of this type of reactor there is clearly observed a blue glow caused by Vavilov-Cherenkov radiation) [2]

The nuclear reactor (Fig. 6) consists of the following main parts [2]: an active zone with nuclear fuel and a neutron moderator; a neutron reflector surrounding the active zone of the reactor; liquid (usually purified water) coolant that takes heat from nuclear assemblies of fuel assemblies and transmits it to the steam generator of the power unit of the nuclear power plant; nuclear chain reaction control systems in the reactor core; emergency protection of the reactor; radiation protection of the reactor; remote control systems for reactor operation.

The data of Fig. 5 clearly demonstrate to the reader the complex nuclear-physical processes taking place in the active zone of a water-water nuclear reactor operating on thermal neutrons. In these processes, the formation of powerful neutron fluxes and fast charged microparticles, which cause intensive Vavilov-Cerenkov radiation in the water coolant of the reactor, takes place in the reactor core. We recall that the Vavilov-Cerenkov effect is due to 
the emission of electromagnetic energy (light) by a charged microparticle moving rapidly with velocity $v_{e}$ in an optically transparent medium, when $v_{e}>c / n[1,3]$, where $c=3 \cdot 10^{8} \mathrm{~m} / \mathrm{s}$ is the speed of light in vacuum; $n$ is the refractive index of the coolant (for water $n \approx 1.33$ [1]).

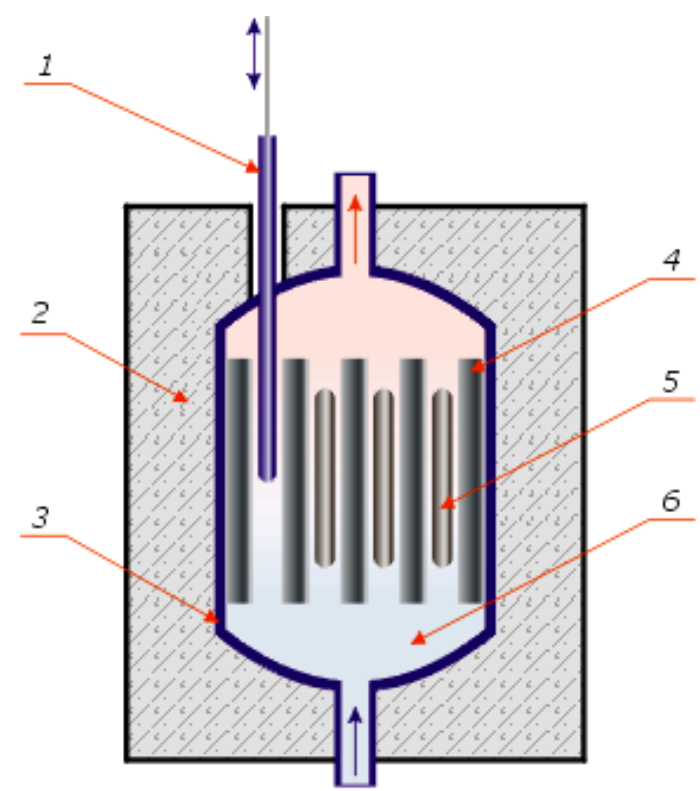

Fig. 6. Simplified diagram of the structure of a heterogeneous nuclear reactor on thermal neutrons $(1-$ control rod, 2 - massive radiation protection, 3 - heat-insulating housing, 4 - neutron moderator, 5 - nuclear fuel, 6 - liquid coolant) [2]

The current state of any nuclear reactor is characterized by two factors [2]: the multiplication factor $k_{p}$ of neutrons in its core and the reactivity $\rho_{p}$. At $k_{p} \approx 1$ and $\rho_{p} \approx 0$, the number of fissions of the uranium isotope nuclei ${ }_{92}^{235} \mathrm{U}$ in the reactor core is constant and the nuclear reactor is in a stable critical state. The conversion of the multiplication factor $k_{p}$ of neutrons to unity is achieved by balancing the process of neutron multiplication in the reactor core and their losses. There are two main causes of neutron loss in a nuclear reactor $[2,8]$ : the first is the capture of neutrons by uranium nuclei without their fission; the second is the neutron escape from the reproduction zone. Control of the nuclear chain reaction of fission of uranium isotope nuclei $k_{p}$ in fuel assemblies is provided by «retarded» neutrons. It is due to the considerable time of «life» in the active zone of the reactor of «delayed» neutrons that its control system manages to move the control rod-absorbers (usually made of boron or cadmium) and thereby select for the nuclear reactor the necessary multiplication factor $k_{p}$ of neutrons and accordingly its reactivity $\rho_{p}$. Note that one important circumstance is that in the described nuclear reactor on thermal neutrons the nuclei of natural uranium $92^{238} \mathrm{U}$, capturing fast neutrons from fission of uranium isotope nuclei ${ }_{92}^{238} \mathrm{U}$ or neutrons in the process of their deceleration, do not test their division. Such excited uranium nuclei ${ }_{92}^{238} \mathrm{U}$ in the process of a long chain of nuclear transformations (for a time of up to 2.3 days) pass to the stable nuclei of the weapon isotope of plutonium ${ }_{94}^{239} \mathrm{Pu}$, which, like the nuclei of the uranium isotope ${ }_{92}^{238} \mathrm{U}$, can be divided in the uranium assemblies of the reactor fuel assembly thermal neutrons $[1,3]$.
1.1.1. Classification of nuclear reactors. According to the design, modern nuclear reactors of nuclear power plants are divided into two large groups [11]:

- channel reactors (fuel assemblies in them are placed in separate channels that penetrate its active zone and are made in graphite blocks of neutron moderators, assemblies with each other can be swapped and flowed by the flow of a liquid heat carrier);

- hull reactors (fuel assemblies in them are permanently located inside a massive metal casing, and the active zone is washed by an intensive flow of liquid heat carrier).

Fig. 7, 8 show the general views of the channel and hull types of nuclear reactors used at Ukrainian NPPs, respectively $[2,9,12]$.

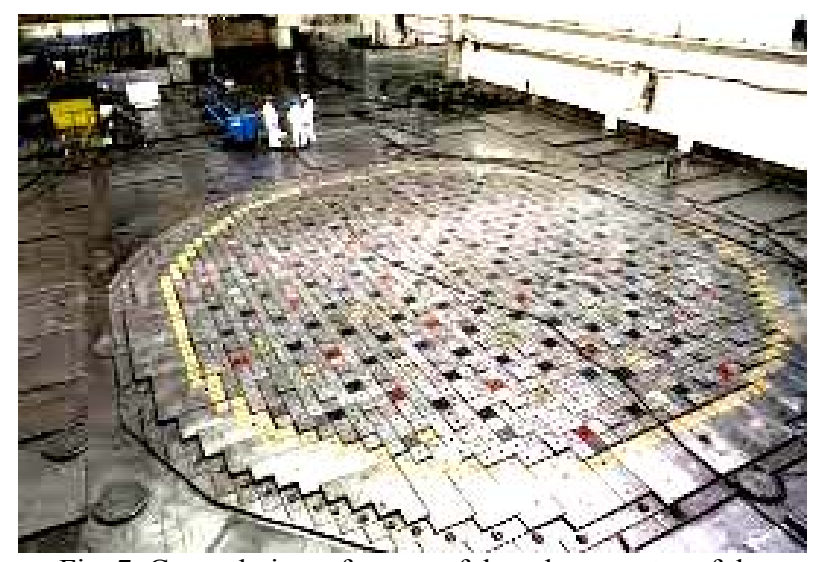

Fig. 7. General view of a powerful nuclear reactor of the RBMK-1000 type installed in the reactor plant of one of the 4 operated power units of the Chernobyl nuclear power plant

(before the catastrophe in 1986) from its assembled of

separate lead blocks of the upper protective cover $[2,9]$

As is known, in April 1986 on the 4th power block of the Chernobyl NPP, it was exactly on the RBMK-1000 nuclear reactor of high power of the channel type with thermal power of $1000 \mathrm{MW}$ that the most serious accident in the world nuclear power history took place which undermined people's confidence in the safety of nuclear reactors. Some countries (for example, Italy) after the catastrophe at the Chernobyl nuclear power station passed laws prohibiting the location of nuclear power plants on its territory (the existing nuclear power plants were stopped and their nuclear reactors conserved) [8]. In Germany, government decisions have been taken to reduce the number of nuclear power plants operating on its territory $[2,8]$.

At present, the most secure design of a powerful nuclear reactor on thermal neutrons used in modern nuclear power plants is shown in Fig. 8 design of the WWER-1000 reactor $[9,12]$. The overall dimensions of such a nuclear reactor are [9]: the height is up to $20 \mathrm{~m}$ and the hull diameter is up to $4.5 \mathrm{~m}$. Control and regulation of the process of the chain nuclear reactions in the assemblies of fuel assemblies filled with uranium fuel elements of plate or cylindrical shape, and the process of heating the water coolant of a nuclear reactor of the WWER-1000 type is carried out with the help of rods of the control and protection system (CPS) and a block of protective tube (BPT). The housing of such a reactor is 
calculated for the maximum pressure of an overheated mixture of its water coolant which is about $160 \mathrm{~atm}$ [8].

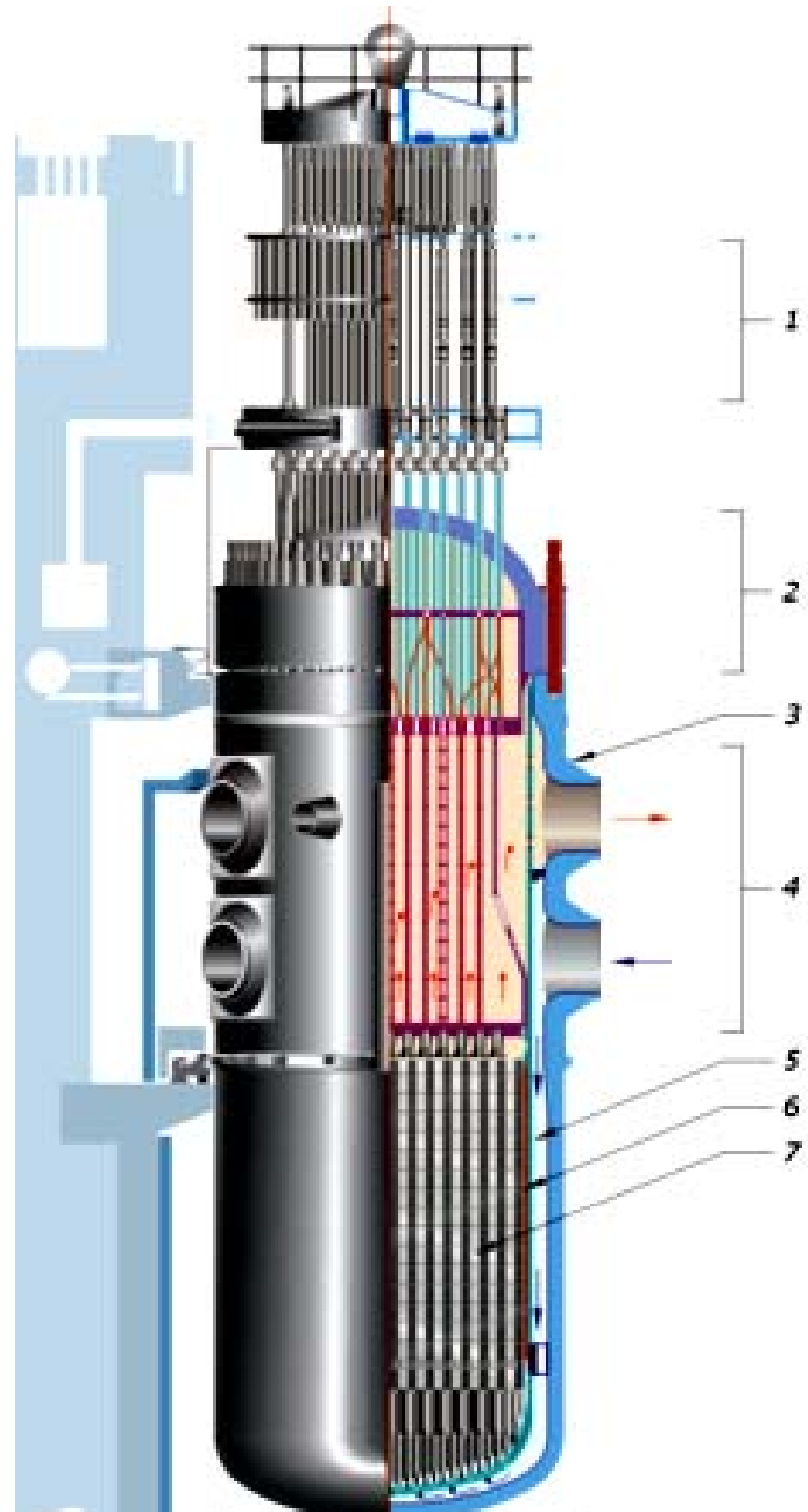

Fig. 8. The scheme of the structure of a powerful nuclear reactor of the WWER-1000 type ( 1 - drive of the CPS, 2 - protective cover of the reactor, 3 - reactor housing, 4 - block of the BPT,

5 - water shaft, 6 - core fence, 7 - fuel assemblies) [9]

It is interesting that the geometric shape of a nuclear reactor is chosen from the condition of a minimum ratio of the area of its massive radiation-resistant enclosure to the volume it occupies. This condition corresponds to the shape of a sphere, a short cylinder, and a cube [1]. This is done to minimize the leakage of neutrons from the core of the nuclear reactor, which has a critical volume in the critical state of the reactor $\left(k_{p} \approx 1 ; \rho_{p} \approx 0\right.$ ) (for modern nuclear reactors this volume can be hundreds of $\mathrm{m}^{3}[2]$ ). The critical volume of the reactor corresponds to the critical mass of the fissionable nuclear fuel. We note that nuclear reactors have the lowest critical mass, in which the water solutions of the salts of pure fissile radioactive isotopes with a water neutron reflector serve as fuel. For example, for the uranium isotope ${ }_{92}^{235} \mathrm{U}$, the lowest critical mass is $0.8 \mathrm{~kg}$, and for the isotope of plutonium
${ }_{94}^{239} \mathrm{Pu}-0.5 \mathrm{~kg}[2]$. As the nuclear fuel «burns out», the reactivity $\rho_{p}$ of the reactor under consideration decreases. In this regard, its assembly of fuel assemblies is required to be changed. In WWER-1000 reactors, replacement of «burnt out» nuclear fuel is produced immediately from their entire core, and in RBMK-1000 reactors such a replacement is carried out gradually with the remaining fuel assemblies of different «ages» in operation. We recall that under the active zone of the reactor is meant the zone where the nuclear fuel is located, the controlled chain nuclear reaction of fission of its nuclei proceeds and where the intranuclear energy is allocated. Fig. 9 shows the time of replacement of nuclear fuel in a reactor of the WWER-1000 type.

Nuclear reactors according to the type of nuclear fuel used in their core are divided into $[2,11]$ :

- reactors with fuel assemblies based on such isotopes of uranium as ${ }_{92}{ }^{238} \mathrm{U},{ }_{92}{ }^{235} \mathrm{U}$ and ${ }_{92}{ }^{233} \mathrm{U}$;

- reactors with fuel assemblies based on the isotope of plutonium ${ }_{94}^{239} \mathrm{Pu}$, a whole family of plutonium isotopes ${ }_{94}^{239-242} \mathrm{Pu}$ in a mixture with natural uranium ${ }_{92}{ }^{238} \mathrm{U}$;

- reactors with fuel assemblies based on the thorium isotope ${ }_{90}^{232} \mathrm{Th}$ (with further conversion when staying in the core in the uranium isotope ${ }_{92}^{233} \mathrm{U}$ ).

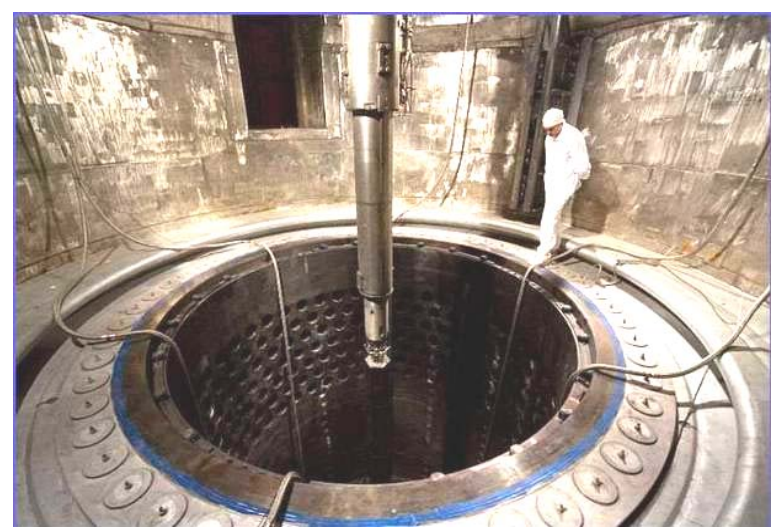

Fig. 9. Loading of fresh fuel (fuel assemblies) into a powerful water-water nuclear reactor of the WWER-1000 type (the upper hermetic protective cover of the reactor was removed) $[2,9]$

Nuclear reactors according to the nature of the location of fuel in the core are classified into [2]:

- heterogeneous reactors (fuel in their zone is placed discretely in the form of blocks (fuel assemblies streamlined by the coolant), between which there is a neutron moderator);

- homogeneous reactors (fuel and neutron moderator represent a homogeneous mixture).

Nuclear reactors differ in the degree of enrichment of their nuclear fuel in fuel elements by $[2,11]$ :

- reactors with fuel assemblies based on the isotope of unprocessed natural uranium ${ }_{92}^{238} \mathrm{U}$;

- reactors with fuel assemblies based on the isotope of poorly enriched natural uranium ${ }_{92}^{238} \mathrm{U}$;

- reactors with fuel assemblies based on the isotope of highly enriched natural uranium ${ }_{92}^{238} \mathrm{U}$.

Nuclear reactors for the chemical composition of fuel in the core are divided into $[2,11]$ :

- reactors with metal isotopes of uranium, plutonium and thorium; 
- reactors with uranium dioxide $\mathrm{UO}_{2}$;

- reactors with uranium carbide UC.

Nuclear reactors in the energy spectrum of neutrons in the core are divided into $[2,11]$ :

- reactors on thermal (slow) neutrons called «thermal reactors»;

- fast neutron reactors called «fast reactors»;

- reactors on intermediate neutrons;

- reactors on neutrons with a mixed energy spectrum.

Nuclear reactors by type of coolant in their core are divided into [2, 11]:

- reactors with light water $\mathrm{H}_{2} \mathrm{O}$ called «water-water nuclear reactors»;

- reactors with heavy water $\mathrm{D}_{2} \mathrm{O}$ called «heavy water nuclear reactors»;

- reactors with gas in the core called «graphite-gas nuclear reactors»;

- reactors with a liquid-metal coolant (for example, with sodium, a liquid mixture of lead with bismuth);

- reactors with organic coolant;

- reactors with solid coolant;

- reactors on melts of a number of salts (for example, uranium fluorides).

Nuclear reactors according to the type of neutron moderator used in their zone are divided into $[2,11]$ :

- reactors with graphite $C$ designed as «graphite-water and graphite-gas reactors»;

- reactors with light water $\mathrm{H}_{2} \mathrm{O}$ designed as «light water and water-water reactors»);

- reactors with heavy water $\mathrm{D}_{2} \mathrm{O}$ designed as «heavy water reactors»;

- reactors with metallic beryllium Be (can be made with beryllium oxide $\mathrm{BeO}$ );

- reactors with hydrides of a number of metals;

- reactors without moderator called «fast neutron reactors».

Nuclear reactors differ in the way they generate heat carrier vapor in $[2,11]$ :

- reactors with an external steam generator designed as «water-water reactors» (for example, two-circuit reactors of the WWER-1000 type);

- reactors with internal generation of steam, performed as «boiling reactors» (for example, RBMK1000 single-loop reactors).

Nuclear reactors, according to the nature of their purpose and use, are divided into [2, 11]:

- power reactors used to generate electricity and heat (these reactors are installed at NPPs);

- transport reactors placed on vehicles (for example, on military submarines);

- industrial reactors used for the production of the weapon isotope of plutonium ${ }_{94}^{239} \mathrm{Pu}$ and the production of radioactive isotopes used in various fields (for example, in medicine);

- research reactors in which neutron and gamma-ray fluxes generated in their active zones are used to study the behavior of various substances with respect to the problems of nuclear physics, solid state physics, radiation chemistry, radiobiology, and radiology;
- experimental reactors designed to determine in the conditions of intensive neutron and thermal fields of various physical and technical properties of structural materials necessary for the design and operation of new designs of nuclear reactors at NPPs and nuclear special purpose plants.

As we can see, nuclear reactors are characterized by a wide range of their classification. The International Atomic Energy Agency (IAEA) uses the following classification of the main types of nuclear power reactors at nuclear power plants $[2,12]$ :

- PWR - pressurized water reactor in which light water $\mathrm{H}_{2} \mathrm{O}$ is both a coolant and a retarder (for example, a WWER-1000 water-water reactor);

- LWGR - light water graphite reactor - reactor with light water $\mathrm{H}_{2} \mathrm{O}$ as a coolant and with graphite as a moderator (for example, «graphite-water reactor» type RBMK-1000);

- BWR - boiling water reactor in which the formation of steam from a single-circuit circuit to a steam turbine occurs directly in the reactor;

- GCR - gas-cooled reactor in which gas is used as the heat carrier, and moderated block graphite;

- FBR fast breeder reactor which does not require the presence of a moderator in the core, and uses a liquid metal coolant (usually sodium) in the primary circuit, and in the second circuit - light water $\mathrm{H}_{2} \mathrm{O}$;

- HTGR - high-temperature gas-cooled reactor;

- PHWR - pressurized heavy water reactor $-\mathrm{D}_{2} \mathrm{O}$ heavy water reactor as a moderator and coolant;

- HWGCR - heavy-water-moderated gas-cooled reactor - reactor in which gas is used as a coolant, and heavy water $\mathrm{D}_{2} \mathrm{O}$ as a retarder;

- HWLWR - heavy-water-moderated boiling lightwater-cooled reactor - reactor in which heavy water $\mathrm{D}_{2} \mathrm{O}$ is used as a retarder and boiling coolant;

- PBMR - pebble bed modular reactor - modular reactor with spherical structures of its fuel assemblies.

In the nuclear power industry and in powerful nuclear power plants of various countries, the most widespread are «water-water nuclear reactors» (up to $62 \%$ ) and «boiling nuclear reactors» (up to $20 \%$ ) [2, 8].

1.1.2. Fuel for nuclear reactors of Ukrainian NPPs. Until 2011, nuclear fuel (uranium fuel assemblies) for all Ukrainian NPPs was supplied by the Russian company TVEL [13]. In 2008, our country set a course for diversifying nuclear fuel supplies for its nuclear power plants. To this end, in the same year, an agreement was concluded with the Westinghouse Electric Company (USA) to supply it to Ukraine during 2011-2015. 630 pieces of uranium assemblies for 3 powerful power units of domestic NPPs with nuclear reactors of WWER-1000 type [13]. In April 2012, the experimental operation of uranium fuel assemblies produced by the American company Westinghouse Electric Company at the 3rd power unit of the South Ukrainian Nuclear Power Plant revealed a number of serious design errors in these fuel assemblies that caused damages to the Ukrainian side amounting to about USD 175 million [13]. The operation of this unit of the South Ukrainian NPP was continued only after the installation of new assemblies of fuel 
assemblies produced by the RF instead of damaged American nuclear fuel assemblies. According to the State Statistics Committee of Ukraine, during the period January-October 2015, the volume of nuclear fuel imports to our country amounted to USD 504 million including supplies from Russia in the amount of USD 471 million (94\%) and Sweden (from the US supplier Westinghouse Electric Company ) for the amount of USD 33 million USA (6 \%) [13]. Currently, the world-famous Russian company TVEL remains the main supplier of nuclear fuel for our nuclear power plants, providing at least $90 \%$ of the necessary needs of Ukraine for this fuel. As of December 2016, Westinghouse Electric Company (USA) supplied nuclear fuel to a limited extent only for the 3rd power unit of the South Ukrainian Nuclear Power Plant and the 5th power unit of the Zaporizhzhya NPP [13].

1.1.3. Utilization and storage of spent nuclear fuel at Ukrainian NPPs. During the operation of the nuclear reactor, because of the accumulation of fission fragments in its uranium fuel, its isotopic and chemical composition changes and the formation of transuranium elements (mainly plutonium isotopes ${ }_{94}{ }^{244} \mathrm{Pu}$ ) occurs [2, 11]. The spent nuclear fuel (SNF) in the core of the reactor at nuclear power plants is due to its residual heat release to relatively long storage. This residual heat release in SNF is a consequence of gamma and beta decays in radioactive fission products of nuclear fuel accumulated in assemblies during the operation of the nuclear reactor. In SNF, the excited nuclei of these fission products, due to their radioactive decay, become more stable or completely stable, with significant thermal energy released. In this connection, the residual heat generation in SNF is an important problem for working NPPs, directly related to their nuclear safety. To solve this unavoidable problem, special dry or wet SNF storage facilities should be located at the nuclear power plant, in which the latter, under a certain temperature regime, must remain for a sufficiently long time (for example, up to 3-4 years in their waterholding basins) [2]. Since 2001, Ukraine has only one dry SNF storage facility at Zaporizhzhya NPP. We also have one wet SNF storage in the exclusion zone of the Chernobyl nuclear power plant, which is unable to take SNF even from its nuclear power plants for long-term storage [2]. Currently, only two countries in the worldRussia and France possess SNF reprocessing technologies. Therefore, now SNF from Khmelnitsky, Rivne and South-Ukrainian NPPs is exported for storage and processing in Russia. Such technological procedures cost Ukraine annually USD (150-200) million [13].

Due to the high cost of SNF storage in the territory of the Russian Federation and the Ukraine's obligations to the IAEA in the zone of alienation of the Chernobyl nuclear power plant, the construction of the Central SNF storage facility is planned [13]. Since September 2016, technical documentation for the construction in Ukraine of such a dry large SNF storage facility is undergoing international expertise. The creation of such a SNF storage will allow domestic nuclear power plants to diversify the utilization of radioactive waste from their reactors.

1.1.4. Safety of nuclear power plants and their nuclear reactors. At present, the high degree of safety of nuclear power plants in many countries of the world is provided by the following basic protective factors $[13,14]$ :

- the principle of self-protection of the nuclear reactor of nuclear power plants (the composition of the reactor core and the physics of the nuclear processes taking place in it on the basis of natural feedbacks due to the appearance of the effect of «negative reactivity» should ensure its self-regulation);

- availability of emergency protection at nuclear reactors and number of radiation safety barriers;

- multiple duplication of safety channels at nuclear power plants and the use of protective systems, both active (requiring intervention of maintenance personnel and the availability of a power supply source) and passive (not requiring intervention by maintenance personnel and the availability of a power source) of a protective nature;

- using materials that are highly resistant to the effects of intense radiation and thermal fields, electrical devices, technological systems and control systems (including their apparatus and cable-conductor products);

- introduction of a safety culture (from the moment of choosing a site for NPP construction up to the period of its launch and during its operation).

Nuclear reactors that remain at the operating power units of Ukrainian NPPs belong to WWER reactors, of which two are WWER-440 type (with installed power of $440 \mathrm{MW}$ ) and 13 WWER-1000 type (with installed power of $1000 \mathrm{MW})$ [13]. These reactors have two-circuit circuits (see Fig. 2) which are fundamentally more safe than the single-loop reactor scheme of the Japanese NPP «Fukushima-1» [8]. In the first circuit of the WWER-type reactor, because of the high pressure in it, there is no saturated vapor. Therefore, the risk of «denuding» (leaving without a coolant) and overheating of its nuclear fuel is fundamentally lower than in a single-loop reactor. The radiation safety system of modern NPPs in Ukraine and Russia (it is necessary not to lose sight of the fact that domestic nuclear power plants and their nuclear reactors are Russian developments) includes four main barriers to the spread of ionizing radiation and radioactive substances into their environment $[13,14]$ :

- a fuel matrix that prevents the release of fission products under the sheath of fuel assembly;

- a zirconium-steel sheath of fuel assembly which does not allow the products of fission of fuel to enter the coolant of the main circulation circuit;

- the main circulation circuit (1st circuit) which prevents the fission products from escaping under the protective hermetic shell of the reactor;

- a system of protective hermetic shells («containment») of the reactor excluding the release of nuclear fission products into the environment.

Fig. 10 shows a simplified scheme for the containment of a nuclear reactor of the WWER-1000 type [14].

We point out that the containment of a nuclear reactor of the WWER-1000 type with a volume of up to $75000 \mathrm{~m}^{3}$, made of prestressed concrete with metal cables, is mechanically designed as an external force (for example, to drop an aircraft at speed of up to $200 \mathrm{~m} / \mathrm{s}$ and a mass up to 5 tons), and on the internal action of gases 
accumulated in an emergency mode in the reactor zone with an excess pressure of up to 5 atm [14]. In addition, this container of a nuclear reactor of the WWER type is able to withstand the impact of an air shock wave with a pressure up to $30 \mathrm{kPa}$ on its front, a seismic effect from a calculated earthquake with an intensity of up to 8 points on the MSK-64 scale and hurricane impact with wind speed of up to $56 \mathrm{~m} / \mathrm{s}$ [14].

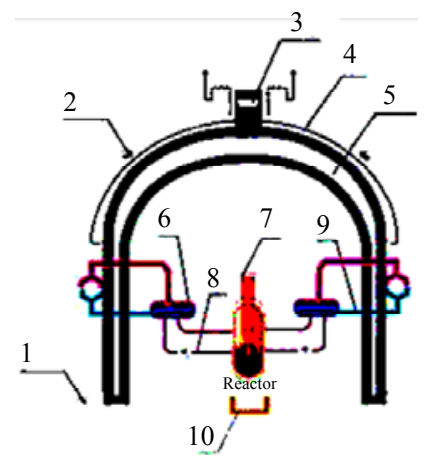

$$
\begin{aligned}
& 1 \text { - atmospheric air } \\
& 2 \text { - hot air } \\
& 3 \text { - filter } \\
& 4 \text { - passive filtration traction } \\
& \text { tubes } \\
& 5 \text { - interblock space } \\
& 6 \text { - steam generator } \\
& 7 \text { - rods with absorber } \\
& 8 \text { - the first loop } \\
& 9 \text { - the second loop } \\
& 10 \text { - melt trap }
\end{aligned}
$$

Fig. 10. Scheme of protective hermetic shells of a nuclear reactor of WWER-1000 type at domestic NPPs [14]

In the event of a severe accident (for example, breaking the pipeline of the first cooling circuit of its core) on the nuclear reactor of the WWER-1000 type, its containment and liquidation, there is an emergency core cooling system (ECCS), containing special tanks with boric acid over the reactor [14]. Each $60 \mathrm{~m}^{3}$ vessel of the ECCS system of the reactor is a thick-walled $(90 \mathrm{~mm}$ thick) cylindrical vessel of bilayer clad steel with a diameter of up to $3175 \mathrm{~mm}$, operating under a pressure of $60 \mathrm{~atm}$ [14]. Rapid delivery of the contents of the abovementioned capacitances of the ECCS to the inside of the core of the nuclear reactor results in the quenching in it of a large amount of boron-containing material that absorbs fast and slow neutrons, chain nuclear reactions in the fuel assemblies, and the removal of the reactor to a minimum thermal power. In the future, according to the rules at NPP, a system for its emergency cooling should be connected to the cooling of the core of the emergency reactor [14]. The principle of deep defense of its nuclear reactors used at nuclear power plants also presupposes the existence of such a concept of nuclear safety, which provides not only means for preventing accidents, but also means for managing the consequences of beyond design basis accidents ensuring the localization of radioactive substances within the confinement. Such means include [14]:

- a hydrogen removal system (with passive recombiners) accumulated in the volume occupied by protective hermetic shells;

- a system for protecting the first circuit of the reactor from exceeding the pressure in its pipelines;

- a system of heat removal from steam generators;

- a system of heat removal from the designs of the protective hermetic shells of the nuclear reactor;

- a device for localization of the core melt («trap»), placed under the reactor.

The emergency protection of the nuclear reactor of the nuclear power plant consists of a set of devices designed to quickly stop the nuclear chain reaction in the reactor core. This protection automatically works when one of the parameters of the nuclear reactor reaches a value that could lead to its failure. [2]: temperature, pressure and flow rate of the heat carrier (in the first radioactive circuit of the WWER-type reactor), the level and rate of increase in the reactor power. In most cases, active elements of the active emergency protection of a nuclear reactor at nuclear power plants are rods with a substance that absorbs neutrons well (for example, boron or cadmium). Sometimes a liquid absorber injected under pressure into its radioactive coolant circuit is used to stop a nuclear reactor. In addition to active emergency protection, modern nuclear reactors also provide systems for their passive emergency protection (for example, the indicated ECCS system) [14].

In accordance with the «Rules of Nuclear Safety of Nuclear Plant Reactor Systems» in force in Ukraine and the Russian Federation, at least one of the envisaged reactor shutdown systems should perform the function of emergency protection of the nuclear reactor of nuclear power plants [12-16]. The emergency protection equipment for a nuclear reactor of a nuclear power plant must at the same time consist of at least two independent staffing sets. Each set of emergency protection equipment of the reactor should be designed in such a way that in the entire range of technological parameters set in the reactor plant design, an emergency protection is provided by at least three independent channels for each process parameter to be protected $[15,16]$.

It is important to note that at all NPPs in Ukraine and the Russian Federation, automatic radiation monitoring systems (ARMS) have been installed that fix the radiation level around radiation-hazardous NPP facilities in real time using a sensor network. The readings of the ARMS devices are transmitted to a special website in Internet.

1.2. The world's largest nuclear power plants. It should be noted that in 1978 in the world around a hundred nuclear reactors of various types and capacities operated in the nuclear power plant, in April 2017, the number of nuclear power units operating in the industrialized countries of the world (including temporarily suspended) was 451 [2]. The largest operating NPP in Europe is the Zaporizhzhya NPP (Energodar, Zaporizhzhya region, Ukraine) with installed power of $6000 \mathrm{MW}$, the construction of which began in 1980 [8]. Since 1996, six powerful dual-circuit power units with «water-water nuclear reactors» of the WWER-1000 type have been operating in the structure of this NPP (see Fig. 8). The world's largest nuclear power plant with installed power of $8212 \mathrm{MW}$ is located in Kashiwazaki (Niigata prefecture, Japan) [8]. It has five «boiling nuclear reactors» (BWR type according to the IAEA classification) and two improved «boiling nuclear reactors» of the ABWR type [2, 8]. However, since 2011 this NPP does not generate electricity to the grid. Therefore, today the world's largest operating nuclear power plant is the South Korean nuclear power plant «Corey» which has seven powerful power units with «water-water reactors» (type PWR on the IAEA scale) with installed power of $6862 \mathrm{MW}$ [8]. 
1.3. Generation of electricity at nuclear power plants in the world. As of December 31, 2015, nuclear power plants of the world in total produced about $2477 \mathrm{TWh}$ of electricity per year, which amounted to about $10.7 \%$ of the world's electricity generation [8]. The annual «peak» of electricity production at nuclear power plants around the world was recorded in 2006, amounting to $2660 \mathrm{TWh}$. The share of nuclear power in global annual production on our planet of electricity in 2015 compared with 1996 decreased from $17.6 \%$ to $10.7 \%$. The world leaders in terms of the production of electricity at nuclear power plants for 2016 were [8]:

- the USA (805.3 billion $\mathrm{kWh} / \mathrm{year}, 99$ nuclear reactors operated at the NPP, generating up to $19.7 \%$ of the electricity generated in the country);

- France (384 billion $\mathrm{kWh} /$ year, 58 reactors operating at nuclear power plants, generating up to $72.3 \%$ of the country's electricity);

- China (210.5 billion $\mathrm{kWh} / \mathrm{year}, 36$ nuclear reactors operating at nuclear power plants generating up to $3.6 \%$ of the country's electricity), which is currently implementing the world's largest program for the construction of new nuclear power plants;

- Russia (179.7 billion kWh/year, 37 nuclear reactors operated at nuclear power plants, generating up to $17.1 \%$ of the country's electricity);

- South Korea (154.3 billion kWh/year, there were 25 nuclear reactors operating at nuclear power plants generating $30.3 \%$ of the total amount of electricity generated in the country);

- Canada (97.4 billion kWh/year, 19 nuclear reactors, generating up to $15.6 \%$ of the country's electricity);

- Ukraine (81 billion $\mathrm{kWh} /$ year, 15 powerful WWER (PWR) reactors operating at nuclear power plants, generating up to $52.3 \%$ of the country's total electricity generation);

- Germany (80.1 billion kWh/year, 8 nuclear reactors operating at nuclear power plants, generating up to $13.1 \%$ of the country's electricity);

- Great Britain (65.1 billion $\mathrm{kWh} /$ year, 15 powerful nuclear reactors that generate up to $20.4 \%$ of the country's total electricity production);

- Sweden (60.6 billion kWh/year, 10 nuclear reactors, generating up to $40 \%$ of the country's electricity, and the state program for the abandonment of nuclear power in the country was suspended).

From the above quantitative data for nuclear power plants in a number of countries, it can be seen that almost half of the world's annual electricity generation at nuclear power plants falls on only two countries - the United States and France. Now 31 countries of the world are using NPPs [8]. The overwhelming number of operating nuclear power plants are located in Europe, North America, Far East Asia and in the territory of independent countries formed from the collapse of the former USSR in $1991[2,8]$.

1.4. Nuclear energy of Ukraine. At present, 15 power units of four powerful NPPs with nuclear reactors of the WWER-440 and WWER-1000 type [13] are producing electricity in Ukraine: 13 Zaporizhzhya, Rivne, Khmelnitsky and South-Ukrainian NPPs (four powerful power units with RBMK-1000 reactors of the Chernobyl nuclear power plant completed their work: in 1986 - the 4th power unit, in 1991 - the second power unit, in 1996 - the first power unit, and in 2000 - the third power unit). In terms of the number of nuclear power reactors (all WWER-type «water-water reactors» or PWR type according to the IAEA classification) Ukraine ranks 5th in Europe and 10th in the world [13]. We point out that Ukraine inherited 12 power units at its nuclear power plants from the former USSR. During the independence of our country, three power units of nuclear power plants (in 1995 and 2000) were completed and put into operation, which were more than $80 \%$ ready for the former USSR. The total electrical power of all NPPs in Ukraine in 2016 was about 130 TW. As indicated above, the contribution of Ukraine's nuclear power in 2016 to the annual energy balance amounted to about $52.3 \%$ of the total electricity production in the country. Since autumn 2014 , the generation of electricity at nuclear power plants in Ukraine has exceeded $50 \%$ of its total output, which was due to a decrease in the capacity of domestic power engineering because of the fighting in the antiterrorist operation zone in the Donbass and the shortage of coal needed for thermal power plants (TPP) of the country [13].

Table 1 shows the main data on domestic nuclear power plants that produce electricity.

Table 1

Data on powerful nuclear reactors and power units of Ukrainian NPPs [13]

\begin{tabular}{|c|c|c|c|c|}
\hline NPP name & Power unit & Reactor type & \begin{tabular}{|c|} 
Power, \\
MW
\end{tabular} & Fuel \\
\hline \multirow{6}{*}{ Zaporizhzhya } & 1 & WWER-1000 & 1000 & TVEL \\
\hline & 2 & WWER-1000 & 1000 & TVEL \\
\hline & 3 & WWER-1000 & 1000 & TVEL \\
\hline & 4 & WWER-1000 & 1000 & TVEL \\
\hline & 5 & WWER-1000 & 1000 & $\begin{array}{l}\text { TVEL } \\
+\mathrm{WH}^{*}\end{array}$ \\
\hline & 6 & WWER-1000 & 1000 & TVEL \\
\hline \multirow{4}{*}{ Rivne } & 1 & WWER-440 & 440 & TVEL \\
\hline & 2 & WWER-440 & 440 & TVEL \\
\hline & 3 & WWER-1000 & 1000 & TVEL \\
\hline & 4 & WWER-1000 & 1000 & TVEL \\
\hline \multirow{4}{*}{ Khmelnitsky } & 1 & WWER-1000 & 1000 & TVEL \\
\hline & 2 & WWER-1000 & 1000 & TVEL \\
\hline & 3 & WWER-1000 & \begin{tabular}{|c|}
$\begin{array}{c}\text { Conserv } \\
\text { ated }\end{array}$ \\
\end{tabular} & TVEL \\
\hline & 4 & WWER-1000 & $\begin{array}{c}\text { Conserv } \\
\text { ated }\end{array}$ & TVEL \\
\hline \multirow{4}{*}{$\begin{array}{l}\text { South- } \\
\text { Ukrainian }\end{array}$} & 1 & WWER-1000 & 1000 & TVEL \\
\hline & 2 & WWER-1000 & 1000 & TVEL \\
\hline & 3 & WWER-1000 & 1000 & $\begin{array}{l}\text { TVEL } \\
+\mathrm{WH}^{*}\end{array}$ \\
\hline & 4 & WWER-1000 & $\begin{array}{c}\text { Conserv } \\
\text { ated }\end{array}$ & TVEL \\
\hline
\end{tabular}

Note*. In Table 1 in the column «Fuel», the WH symbols denote the partial use of the US Westinghouse Electric Company's uranium assemblies at the same time as assemblies of TVEL, Russia [13].

From the data of Table 1 it can be seen that at present two powerful power units of Khmelnytsky (No. 3 
and No. 4) and one powerful power unit (No. 4) of the South-Ukrainian NPP are suspended and all construction work on them is «frozen». I would like to hope that with the creation in a number of years in the zone of alienation of the Chernobyl nuclear power plant of the Central dry storage of SNF, a certain part of Ukraine will not turn into a large radioactive «dump» of both its own nuclear waste and nuclear waste from nuclear power plants supplied to Ukraine from Europe and North America.

Fig. 11-13 present, respectively, the general views of the South-Ukrainian NPP, the power plant hall of one of its powerful power units and one of its block control panels (BCP) [17]. This domestic nuclear power plant located on the picturesque bank of the Southern Bug river at altitude of $130 \mathrm{~m}$ above the level of the Baltic Sea is not threatened by strong earthquakes or tsunamis. The design of the technical facilities of this domestic nuclear power plant and its nuclear facilities provides protection from all sorts of natural disasters and shock effects of various external factors (for example, a falling aircraft) [17].

The leakage of nuclear chain reactions in uranium fuel assemblies with TVEL and, in part, with the uranium elements of the US Westinghouse Electric Company (at the $3^{\text {rd }}$ power unit of the station) of each of the three operating power units with powerful WWER-1000 reactors at this nuclear power plant of Ukraine is clearly controlled with the BCP (see Fig. 13) using the CPS.

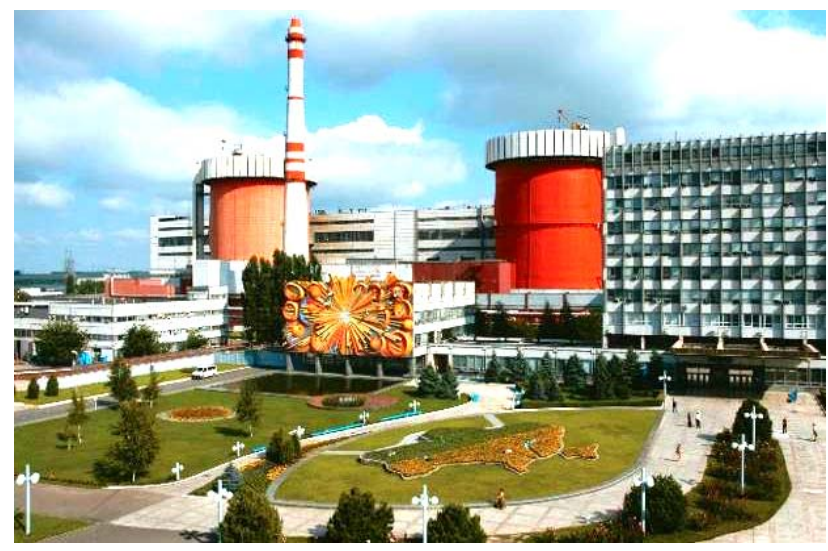

Fig. 11. General view of the fragment of the South-Ukrainian NPP with the total installed power of $3000 \mathrm{MW}$ (Yuzhnoukrainsk, Mykolayiv region, Ukraine) [17]

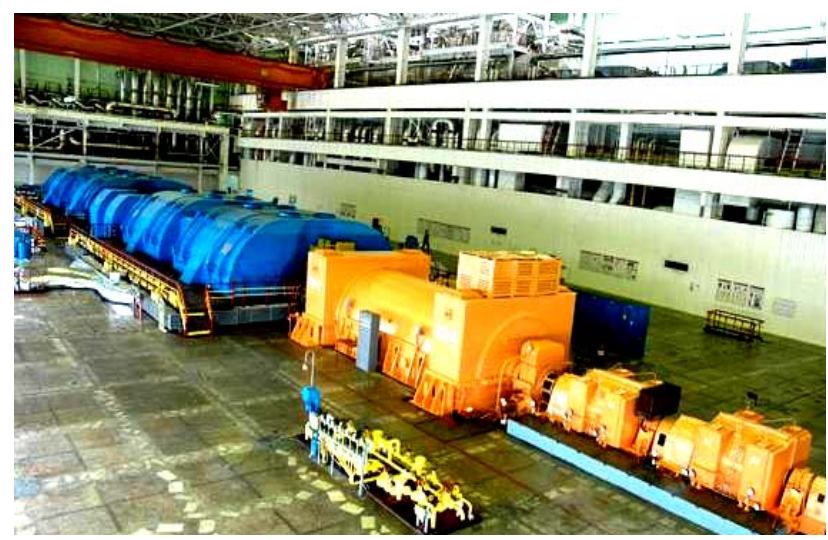

Fig. 12. General view of the power plant hall of the power unit with the thermal power of $1000 \mathrm{MW}$ of the South-Ukrainian NPP [17]

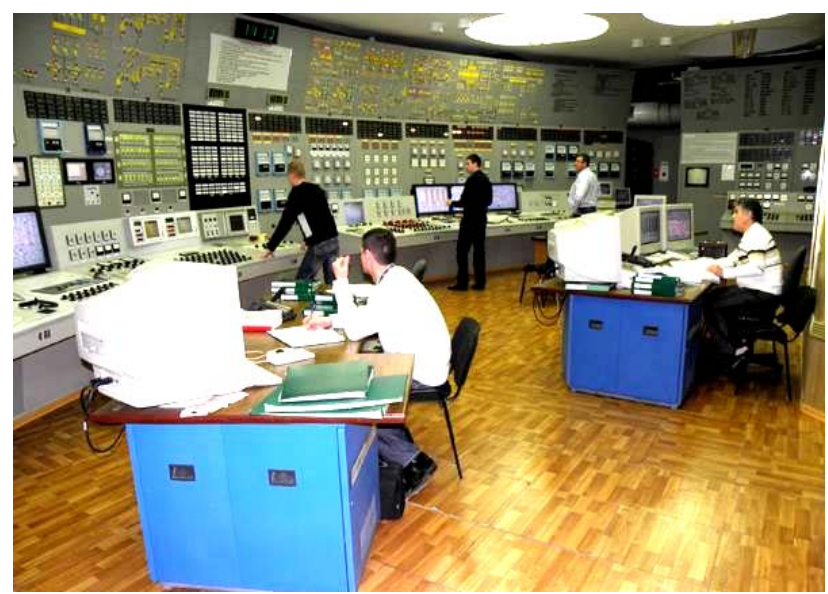

Fig. 13. General view of the block control panel (separate specific «command post») of one of the power units with thermal power of $1000 \mathrm{MW}$ at the South-Ukrainian NPP [17]

Omitting and raising with the help of the CPS system special boron rods that actively absorb neutrons in the active zone of a nuclear reactor of the WWER-1000 type, the operational personnel of the power units of this NPP can slow down or accelerate the chain nuclear reactions in its uranium fuel assemblies. A highly reliable CPS system at each powerful power unit of the domestic NPP under review allows the reactor shutdown to stop the operation of the appropriate nuclear reactor («shut down» the reactor) $[2,17]$. The reader needs to remember that the withdrawal of a nuclear reactor to a minimum thermal power (its stop) leads to its «poisoning».

In nuclear physics, the state of the nuclear reactor after its shutdown and «poisoning» was called «iodine well» [2]. This abnormal state of the reactor is characterized by the accumulation in its active zone of the short-lived radioactive isotope of xenon ${ }_{54}^{135} \mathrm{Xe}$ (with a half-life of 9.2 hours), which in turn is the product of the radioactive decay of the intermediate isotope of iodine ${ }_{53}^{135} \mathrm{I}$ (with a half-life of 6.8 hours) $[2,11]$. Because the ${ }_{54}^{135} \mathrm{Xe}$ xenon isotope has the largest neutron absorption cross section (up to $2.6 \cdot 10^{6}$ barn $[1,2]$ ), the nuclear reactor in the «iodine well» state loses its reactivity $\rho_{p}$ (it becomes negative) and, correspondingly, the thermal power. This makes it difficult to bring the reactor to its designed capacity for a time measured by (1-2) days $[2,8]$. In this regard, such conditions for the nuclear reactor of nuclear power plants are undesirable. Therefore, short-term reactor shutdown at nuclear power plants and fluctuations in its output thermal power can not be made. It is allowed to stop the nuclear reactor only in the event of an emergency regime provided for by the relevant Rules (see 1.1.4).

1.5. The harmful effect of nuclear power plants on the environment. For a better understanding of the relevant environmental issue related to nuclear energy, the reader needs to be reminded that, for example, each powerful WWER-1000 reactor at domestic nuclear power plants with its full nuclear fuel loading contains 54 uranium fuel assemblies with a total mass of 41 tons at the total number of TVELs in them is 48 thousand pieces [8]. In a nuclear reactor of a modern nuclear power plant, about 300 kinds of radionuclides are formed from uranium fuel through nuclear transformations, of which 
more than 30 as gas-aerosol emissions from the volume of its containment, in spite of the corresponding protective filters available in it, can enter the air atmosphere [8]. Among them, radioactive substances such as [11]: the cesium isotope ${ }_{55}^{137} \mathrm{Cs}$ (with a half-life of 30 years), the iodine isotope ${ }_{53}^{131} \mathrm{I}$ (with a half-life of 8 days), the iodine isotope ${ }_{53}^{133} \mathrm{I}$ (with a half-life of 20.8 hours) and the xenon isotope ${ }_{54}^{138} \mathrm{Xe}$ (with a half-life of 17 minutes). It should be noted that the operational regulations in force at the nuclear power plants of Ukraine and the Russian Federation permit the presence of up to $1 \%$ of TVEL with a damaged protective zirconium-steel shell in the core of a nuclear reactor (for a two-circuit water-water power reactor of the WWER-1000 type this amounts to about 480 TVEL) $[2,8]$. Through microcracks in TVEL and in the process of recovery of fuel from the reactor during their periodic replacement, radionuclides can enter the water coolant of the primary circuit and into the air under the dome of the containment. Therefore, the abovementioned the safest powerful nuclear reactor of the WWER-1000 type forms about 40 thousand Curies per year (the activity in 1 Curie $(\mathrm{Ci})$ is equal to $3.7 \cdot 10^{10}$ Becquerels $(\mathrm{Bq})$ which is its unit of calculation in the SI system [1]) of gaseous radioactive emissions [8]. Most of them quickly disintegrate and are retained by protective filters of the contaminant. We note that the activity of a radioactive substance in atomic physics is the number of decays of its nuclei in one second. For comparison, it should be noted that single-circuit power reactors of the RBMK-1000 type produce radioactive gaseous emissions at NPPs by almost an order of magnitude compared to two-circuit high-power reactors of the WWER-1000 type [8]. The average daily release of radioactive gases and aerosols at Kursk NPP, still using RBMK-1000 reactors, was in the period 1981-1990 up to 750 Curies per reactor unit (with an annual radioactive indicator of such emissions reaching a level of up to 274 thousand curies) [8]. We point out that most of the radioactivity of gasaerosol emissions at nuclear power plants is generated by short-lived radionuclides and disintegrates without much damage to the environment in a few hours or days. It should also be pointed out that, in addition to the usual gaseous emissions, nuclear power plants occasionally fill up the air atmosphere surrounding them and further pollute nearby areas with a small amount of radionuclides hazardous to human health - products of corrosion of the reactor vessel and its primary circuit, as well as fission fragments of uranium isotope nuclei ${ }_{92}^{235} \mathrm{U}$. These radionuclides can be traced for several tens of kilometers around any nuclear power plant.

1.6. Advantages and disadvantages of nuclear power. The main advantages of nuclear power plants over other competing powerful industrial sources of electrical and thermal energy for humanity today are [8]:

- practical independence from fuel sources due to the relatively small volume of nuclear fuel consumed by any nuclear power plant (for example, for a WWER-1000 reactor for 1.5 years of operation as part of a powerful power unit, only about 41 tons of uranium dioxide $\mathrm{UO}_{2}$ inside fuel assemblies are required, at the same time, for example, for the Zmiev TPP with installed power of $2200 \mathrm{MW}$, two railway coal trains are required for only 1 day [7]);
- relative ecological cleanliness in comparison with TPPs (total annual emissions to the environment of such harmful substances as sulfur dioxide, nitrogen oxides, carbon oxides, hydrocarbons, aldehydes and dust per 1000 MW of installed power at pulverized coal-fired power plants are about 165 thousand tons; $1000 \mathrm{MW}$ of its power consumes about 8 million tons of oxygen $\mathrm{O}_{2}$ from the atmosphere per year, while the NPP does not consume $\mathrm{O}_{2}$ during its operation of atmospheric oxygen at all);

- higher ability to confront energy crisis situations in society and, accordingly, to keep the volume and cost of electricity produced at a level acceptable to its consumers (increase in the world prices for coal, gas and oil increases the competitiveness of nuclear power plants). are [8]:

The main disadvantages of nuclear power plants

- severe consequences for the environment and the population from major accidents and catastrophes on powerful nuclear reactors of nuclear power plants (to exclude such situations, modern nuclear power plants are equipped with complex nuclear and radiation safety systems for their nuclear facilities with redundancy and multiple reserves of resistance of their structures to high radiation and temperature providing exclusion of reactor core meltdown even in the event of a maximum design accident);

- large expenditures of financial resources for the liquidation of technical facilities of nuclear power plants and its power units after the end of their working life by nuclear reactors (according to expert estimates, these costs amount to $20 \%$ of the NPP construction cost, the problem of extending the life of nuclear power units is acute not only for nuclear power in Ukraine, but also of all other countries of the world using nuclear power plants to generate electricity [18]);

- the inability of maneuvering modes of operation of nuclear power reactors of nuclear power plants covering emerging «peaks» and smoothing «dips» on the graphs of their electrical load;

- higher financial costs for NPP construction compared to TPPs of similar installed power (for example, for NPPs, these costs are about USD 2300 per $1 \mathrm{~kW}$ of electric power of their power units, and for pulverized coal-fired TPPs - about USD 1200 per $1 \mathrm{~kW}$ of electric power of power units of such stations).

2. The main problems, trends and prospects for the development of nuclear power plants in the world and Ukraine. The current problems in the field of world nuclear power which are actively engaged in the industrial production of electricity and thermal energy by means of a complex and dangerous for human life technological use of atomic energy of a number of fissile radioactive materials (for example, the uranium isotope ${ }_{92}{ }^{235} \mathrm{U}$ and the isotope of plutonium ${ }_{94}{ }^{239} \mathrm{Pu}[1]$ ), can be reduced to the following $[2,8]$ :

- the problem of developing and creating for NPPs of more advanced by their power efficiency, nuclear power and radiation safety powerful nuclear units with more than $35 \%$ efficiency;

- the problem of minimizing the occurrence of accidents at nuclear power plants of nuclear power plants 
which lead to serious consequences for entire regions of the country and the peoples of neighboring countries;

- the problem of SNF utilization and reprocessing from powerful nuclear reactors of nuclear power plants in the territories of those countries where these nuclear wastes were produced;

- the problem of the presence of a closed nuclear cycle in the territories of those countries that actively use powerful nuclear facilities for the industrial production of electricity and heat in large amounts commensurate with the volumes of generation of these types of energy by their heat power engineering using organic fuels (this problem is especially relevant for Ukraine which due to its limited financial resources is trying to gradually approach it from year to year using even such a difficult path as avoiding direct bonded dependence from the Russian Federation in matters of preserving and further developing its own nuclear power and diversifying supplies to domestic NPPs of uranium fuel assemblies with TVEL from other countries of the world);

- the problem of extending the life of power units of NPPs and, accordingly, the resource of nuclear reactors.

In the world nuclear power industry there is a tendency of aging of nuclear reactors. According to the IAEA, the average «age» of operating nuclear reactors at nuclear power plants in the world is 29 years [8]. The world's «oldest» existing reactor is now in Switzerland which has been working reliably for 47 years. It should be noted that the regulatory life of nuclear power units of NPPs is set by the government of a particular country on the basis of the design life of their reactors of one type or another. Usually this period is from 30 to 40 years [8]. In Ukraine and the Russian Federation, the standard operating life of most types of NPP power units is 30 years $[8,18]$. It is known that extending the life of the power unit of the nuclear power plant is a very costeffective measure. Thus, with a financial cost to extend the life of a powerful nuclear «water-water reactor» of the WWER-1000 type (PWR type according to the IAEA scale) for about 20 years at about USD 90 million, the possible profit from its operation at a NPP for such an additional period may to make about USD 1.3 billion [8, 19]. In Ukraine and the Russian Federation, the operation of two-loop water-water nuclear reactors of the firstgeneration of WWER type and single-loop nuclear reactors of the RBMK type has already been extended to 45 years, and nuclear reactors of the WWER type of the second generation up to 55 years $[2,8,19]$.

In conditions of a relatively fast approaching energy «hunger» in the world and the depletion of hydrocarbon fuel in the earth's crust (according to expert estimates of hydrocarbons for TPPs, the world will suffice only for the next 50-100 years [6]) and the practical inexhaustibility of radioactive uranium nuclear power has real prospects for its further development. Alternative energy (wind energy, solar energy, hydrogen power, geothermal energy, biogas power and small hydropower) has not yet been able to seriously compete with traditional energy (heat power, nuclear power and hydropower). Taking into account a number of the above obvious advantages of nuclear power over other well-known types of modern technologies for generating electricity and heat, at present, despite the existing limitation of peaceful use of atomic energy in several countries of the world (for example, in Italy, Germany, Sweden and the USA [20 ]), we can reasonably say that in the near future, mankind will continue to actively use the possibilities of nuclear energy for the purpose of generating electricity and heat on an industrial scale.

Conclusions. The presented brief analytical scientific and technical review of the retrospective, current state, major achievements, trends and prospects for the development of world nuclear power indicates a tremendous breakthrough in knowledge of mankind about the structure of the microworld of matter and its limited possibilities for peaceful use of the inexhaustible reserves of its intranuclear energy. The world nuclear power is now on the difficult and complex scientific and technical way of its «growing up» (it was only a little more than 60 years since the world's first nuclear power plant was put into operation) and the demonstration of the energy potential of this new for the people progressive industrial technology for obtaining electrical and thermal energy in huge volumes.

Nuclear power, like any other progressive industrial technology, has its own «pluses» and «minuses» for human society and earthly nature in general. Despite its latent radiation danger, with a mortal threat to everything living and existent on Earth, more than once in the modern history of the development of human civilization «bursting out» with the infliction of large human casualties and financial losses on its society, nuclear power engineering with several hundred powerful nuclear power units at the NPPs around the world occupies serious advanced positions in the volumes of annual production of electrical and thermal energy. In Ukraine, these volumes of electricity since 2014 for a number of objective reasons account for at least $50 \%$ of the country's annual energy balance.

Taking into account the limited reserves of organic hydrocarbon fuel for TPPs on the Earth and the practical inexhaustibility of natural radioactive uranium (nuclear) fuel for NPPs on our planet, the world nuclear power has all the possibilities for its further development aimed at meeting the ever growing needs of human society for electricity and thermal energy.

\section{REFERENCES}

1. Kuz'michev V.E. Zakony i formuly fiziki [Laws and formulas of physics]. Kiev, Naukova Dumka Publ., 1989. 864 p. (Rus).

2. Available at: https://en.wikipedia.org/wiki/Nuclear_reactor (accessed 09 August 2017).

3. Baranov M.I. Izbrannye voprosy elektrofiziki: Monografija v 3-h tomah. Tom 1: Elektrofizika $i$ vydajushhiesja fiziki mira [Selected topics electrophysics: Monographs in 3 vols. Vol.1: Electrophysics and outstanding physics of the world]. Kharkov, NTU «KhPI» Publ., 2008. 252 p. (Rus).

4. Baranov M.I. Antologiia vydaiushchikhsia dostizhenii $v$ nauke i tekhnike: Monografiia $v$ 3-h tomakh. Tom 1. [An anthology of outstanding achievements in science and technology: Monographs in 3 vols. Vol.1]. Kharkov, NTMT Publ., 2011. 311 p. (Rus).

5. Baranov M.I. An anthology of the distinguished achievements in science and technique. Part 40: The scientific opening of the method of explosive implosion for the obtaining 
above critical mass of nuclear charge and Ukrainian «track» in the «Manhattan» American atomic project. Electrical engineering \& electromechanics, 2017, no.5, pp. 3-13. doi: 10.20998/2074-272X.2017.5.01.

6. Baranov M.I. Antologija vydajushhihsja dostizhenij v nauke i tehnike: Monografija v 3-h tomah. Tom 3 [An anthology of the distinguished achievements in science and technique: Monograph in 3 volumes. Volume 3]. Kharkiv, PhPB Panov A.N. Publ., 2016. 415 p. (Rus).

7. Available

http://dic.academic.ru/dic.nsf/bse/156142/Атомная электроста нция (accessed 25 May 2017). (Rus).

8. Available

at:

https://en.wikipedia.org/wiki/Nuclear_power_plant (accessed 19 September 2017)

9. Available

https://www.google.ru/search?q=аэc+принцип+работы\&neww indow (accessed 12 October 2016). (Rus).

10. Frish O. Niels Bohr. New York, Publ. S. Rozental, 1967. $137 \mathrm{p}$.

11. Levin V.E. Jadernaja fizika i jadernye reaktory [Nuclear physics and nuclear reactors]. Moscow, Atomizdat Publ., 1979. 420 p. (Rus).

12. Andrushechko S.A., Aforov A.M., Vasilyev B.Yu., Generalov V.N., Kosourov K.B., Semchenkov Yu.M., Ukraintsev V.F. AES s reaktorom tipa WWER-1000. Ot fizicheskih osnov ekspluatacii do evoljucii proekta [AES with a reactor of the WWER-1000 type. From the physical foundations of exploitation to the evolution of the project]. Moscow, Logos Publ., 2010. 604 p. (Rus).

13. Available

https://en.wikipedia.org/wiki/Nuclear power in Ukraine

(accessed 20 August 2016).

How to cite this article:

Baranov M.I. An anthology of the distinguished achievements in science and technique. Part 44: Traditional power engineering. Nuclear power stations: retrospective view, state and prospects of their development. Electrical engineering \& electromechanics, 2018, no.3, pp. 3-16. doi: 10.20998/2074-272X.2018.3.01.
14. Available

at: http://energ2010.ru/Stati/Elektrostanciya/AES/Bezopasnost aes.

15. Available at: https://ria.ru/eco/20090426/169135271.html (accessed 18 November 2016). (Rus).

16. Available

https://ru.wikipedia.org/wiki/Аварийная защита ядерного pe актора (accessed 12 March 2016). (Rus).

17. Available at: https://www.segodnya.ua/ukraine/rabotnikijuzhno-ukrainckoj-aec-nash-reaktor-vyderzhit-dazhe-padeniecamoleta.html (accessed 15 May 2017). (Rus).

18. Domashev E.D., Zenyuk A.Yu., Reisig V.A., Kolesnichenko Yu.M. Some approaches to the solution of the problem of prolonging the resource of power units of Ukrainian AES. Industrial heat engineering, 2001, vol.23, no.6, pp. 108-112. (Rus).

19. Favorskiy O.N. On the energy industry of Russia in the next 20-30 years. Herald of the Russian Academy of Sciences, 2007, vol.77, no.2, pp.121-127. (Rus).

20. Available at: http://economics.studio/kniga-ekonomikaprirodopolzovaniya/plyusyi-minusyi-atomnoy-energetiki76786.html (accessed 14 April 2017). (Rus).

Received 19.12.2017

M.I. Baranov, Doctor of Technical Science, Chief Researcher, Scientific-\&-Research Planning-\&-Design Institute «Molniya» National Technical University «Kharkiv Polytechnic Institute», 47, Shevchenko Str., Kharkiv, 61013, Ukraine, phone +380 577076841 ,

e-mail: baranovmi@kpi.kharkov.ua html (accessed 10 June 2016). (Rus). 